\title{
Gender coherence for development The inclusion of women in peace and development
}

On December 9, 2015, the Consortium for Comparative Research on Regional Integration and Social Cohesion (RISC) proudly co-sponsored a Kapuscinski Development Lecture with the European Commission, the United Nations Development Program (UNDP), the Luxembourgish Ministry of Foreign Affairs and the University of Luxembourg, which was delivered by 2011 Nobel Peace Prize Laureate Leymah Gbowee (http:// kapuscinskilectures.eu/lectures/from-war-to-development-women-lead ing-the-nation/). In order to highlight this inspirational talk given by an extraordinary person, the RISC Consortium, in association with Regions \& Cohesion decided to distribute a call for papers for a special issue on "Women, Peace and Development." Like all of RISC's activities, the call aimed to attract contributions on these themes from different world regions.

The centerpiece of this special issue, contributed by Ms. Gbowee, is entitled "From war to development: Women leading the nation." It discusses many important themes, including intrastate violence, terrorism, peace-building and development policies. Ms. Gbowee describes her own work as a peace activist in Liberia and presents her views on women's movements throughout Africa, especially in states characterized by civil war and the presence of militia groups. One important message of Ms. Gbowee's article states that women are "combatants" in civil war because they are targeted by armed men and violence is often gendered (including extreme violence such as rape). For this reason, Ms. Gbowee argues that women should not be placed in the role of "observers" of peace processes and development strategies. She criticizes peace and development policies for establishing "gender" as a category and separating women's issues from general peace and development frameworks in which women should be included as active participants.

This special issue builds on this message. It recognizes the need to mainstream the treatment of women throughout peace and development frameworks. Specifically, this collection of articles discusses the role of women in peace and development in a variety of policy arenas, including migration and development, management of natural resources and the 
environment, prisons/social policies, economic development, health, and violence and public security.

One of the main research themes developed in the RISC Consortium is policy coherence for development (PCD). This concept/policy tool, which has been championed by supranational organizations such as the United Nations (UN), the Organization for Economic Co-operation and Development (OECD) and the European Union (EU), aims to prevent non-development policies from undermining development strategies. It is a main pillar of the post-2015 Sustainable Development Goals agenda.

While PCD has led to some innovative ideas in relation to the improvement of development strategy efficiency and effectiveness, it remains a policy tool. RISC's research agenda on PCD focuses on the need to reinforce the normative bases of this concept so that it contributes to the promotion of rights-based forms of sustainable development. With this in mind, Regions $\mathcal{E}$ Cohesion presents this special issue, which focuses on the need to normatively integrate women and operationalize women's issues in peace and development debates. Thus far, academic and political PCD discussions have largely ignored normative dimensions, including the roles of women and women's rights in development strategies (as highlighted in Ms. Gbowee's contribution). The special issue highlights the need to mainstream women in development and establish a normative coherence regarding gender that permeates peace and development strategies, both domestically and in the international arena. This approach should aim to ensure "gender coherence for development".

Following Ms. Gbowee's contribution, the academic articles presented here address women's issues in diverse contexts. Edith Kauffer's contribution theoretically analyzes the lack of implementation of transversal development discourses focusing on women by identifying an important double discrepancy: (a) the failure of gender to be operationalized in development strategies and (b) the inability to establish links between gender and public policy. These problems are then illustrated in Sandra Sacchetti's ethnographic study of EU-promoted assisted voluntary return (AVR) programs to Kosovo, which highlights the aforementioned disconnect between the reality of women in many developing contexts and policy strategies formulated at the supranational level. This article analyzes the ineffectiveness of AVR and its negative consequences for female participants who suffer from the incoherence between the misplaced focus of the program on migrants as effective development actors and difficult development contexts in Kosovo, which block the socio-economic integration of women.

The next two contributions to this special issue focus on specific case studies related to violence and women. The first article, by Francisco 
Jiménez Bautista, examines the treatment of women in Spanish prisons where many women contend that structural violence persists as they believe that male inmates receive better treatment than females. Second, Patricia Ravelo Blancas and May-ek Querales Mendoza discuss the problem of feminicide in Mexico and the protest movements that have emerged amongst women in that country in response to a problem that has not been effectively addressed by government officials. These two articles illustrate the difficulties that women must face in conflict situations, and they indicate that women's issues related to violence are often treated as separate discussions from general policy debates over human security and human rights.

The Leadership Forum of this special issue also addresses the role of women in different development contexts. The first contribution is an interview with Khuat Thu Hong, Director of the Institute for Social Development Studies in Hanoi, Vietnam. This country occupies a central place in global development debates because of the perception amongst international organizations that its development strategies have been successful. In this interview, Khuat Thu Hong describes Vietnam's current development, the role of women in these processes and the impacts of development on the situation of women in the country. The description of Vietnam illustrates how women must navigate between traditional social roles and pressure to integrate in globalized economic markets. This is followed by a contribution from Karla Priego and Denise Soares that analyzes the supposed commitment from Mexico's government to gender equality in that country's development strategies. The article specifically examines the commitment to gender equality in Mexico's environmental sector.

Finally, Leadership Forum presents photos from the RISC Consortium's World Family Portrait project. This project highlights the human condition in contemporary times and the need to treat specific social issues in relation to general interaction and understanding between people and communities. It is with this spirit that RISC approaches the subject of "Women, Peace and Development." Ms. Gbowee's contribution illustrates how the participation of women in broader peace and development frameworks can promote social change, even in the most difficult political contexts, and reinforce social cohesion. This perspective represents "gender coherence for development".

The Editors 